\title{
Profilaktyka i leczenie żylnej choroby zakrzepowo-zatorowej u pacjentów chorych na nowotwór złośliwy niepoddawanych operacjom chirurgicznym
}

\author{
Jerzy Windyga
}

Choroba nowotworowa jest jednym z największych, niezależnych czynników ryzyka rozwoju żylnej choroby zakrzepowo-zatorowej (venous thromboembolism - VTE), na którą składa się zakrzepica żył głębokich (deep vein thrombosis - DVT) i zator tętnicy płucnej (pulmonary embolism — PE). Dane epidemiologiczne wskazują, że 20\% wszystkich epizodów VTE wykrywa się u chorych na nowotwór złośliwy. Co więcej, VTE może występować nawet u co 5 pacjenta z nowotworem złośliwym, będąc drugą, po samym nowotworze, najczęstszą przyczyną zgonu w tej grupie chorych. Celem obecnej pracy jest przedstawienie zasad profilaktyki i leczenia żylnej choroby zakrzepowo-zatorowej u pacjentów z nowotworem złośliwym niepoddawanych operacjom chirurgicznym (medical patients), leczonych ambulatoryjnie lub w warunkach szpitalnych. W artykule zostaną także omówione zasady postępowania w sytuacjach szczególnie trudnych, jak na przykład nawrotowa VTE oraz VTE z towarzyszącą małopłytkowością, aktywnym krwawieniem lub niewydolnością nerek.

\section{Prophylaxis and treatment of venous thromboembolism in medical cancer patients}

Malignancy is one of the major independent risk factors for the development of venous thromboembolism (VTE) that involves deep vein thrombosis (DVT) and pulmonary embolism (PE). Epidemiological data indicate that $20 \%$ of all VTE cases occur in cancer patients. Moreover, VTE is reported in up to every fifth patient with malignant neoplasm and is the second (after neoplasm itself) leading cause of death in this group of patients. The aim of this paper is to present the principles of prophylaxis and treatment of venous thromboembolism in medical patients with cancer, either being treated in outpatient or inpatient setting. The paper will also address management of challenging cases, such as recurrent VTE or VTE in a patient with thrombocytopenia, active bleeding or renal insufficiency.

NOWOTWORY Journal of Oncology 2015; 65, 4: 257-265

Słowa kluczowe: żylna choroba zakrzepowo-zatorowa, nowotwór złośliwy, heparyna, antykoagulanty

Key words: venous thromboembolism, cancer, heparin, anticoagulants

\section{Wstęp}

Wystąpienie żylnej choroby zakrzepowo-zatorowej (VTE, venous thromboembolism) jest jednym z najczęstszych i najbardziej obciążających powikłań choroby nowotworowej [1]. Szacuje się, że nowotwór złośliwy zwiększa 4-7-krotnie ryzyko wystąpienia VTE, a to oznacza, że u 5 do nawet 20\% pacjentów z rozpoznanym nowotworem złośliwym rozwinie się w trakcie choroby VTE [2]. Co więcej, pacjenci z nowotworem powikłanym VTE są narażeni zarówno na nawroty VTE (około $21 \%$ zdarzeń rocznie pomimo antykoagulacji), jak i na powikłania krwotoczne (około 12\% zdarzeń rocznie), wynikające przede wszystkim z trudności w kontroli przewlekłej antykoagulacji [3]. W konsekwencji pacjenci chorzy na nowotwór iVTE wymagają dodatkowych 
hospitalizacji i interwencji diagnostyczno-leczniczych, które z jednej strony przyczyniają się do obniżenia jakości życia (HRQoL — health-related quality of life), a z drugiej — istotnie podnoszą ogólne koszty leczenia. Dane piśmiennictwa jednoznacznie wskazują, że VTE pogarsza rokowanie co do czasu przeżycia u pacjentów onkologicznych, uzyskując status niezależnego czynnika ryzyka zgonu oraz będąc drugą (po samym nowotworze) najczęstszą przyczyną zgonu w tej grupie chorych. Co więcej, niedawno opublikowana analiza dokumentacji medycznych ponad $1 \mathrm{mln}$ chorych na nowotwór złośliwy wykazała, że w latach 1995-2003 częstość występowania VTE wzrosła aż o 28\% ( $p<0,0001)$ [4]. Zatem omawiane w obecnym artykule zagadnienie należy do najbardziej palących i aktualnych problemów współczesnej onkologii.

\section{Czynniki ryzyka rozwoju żylnej choroby zakrzepowo-zatorowej u chorych na nowotwory}

Ryzyko rozwoju VTE u pacjentów z nowotworem złośliwym jest kształtowane przez czynniki zależne od: 1) samego nowotworu, 2) sposobu jego leczenia i 3) pacjenta (tab. I). Nowotwory niosące największe ryzyko rozwoju VTE to: rak mózgu, trzustki, jajnika, wątroby, żołądka, ale także nowotwory hematologiczne, zwłaszcza czerwienica prawdziwa, nadpłytkowość samoistna, chłoniaki i szpiczak plazmocytowy [5]. Znaczenie ma nie tylko rodzaj i umiejscowienie nowotworu, ale także stadium jego zaawansowania. Większość nowotworów wykazuje ekspresję czynnika tkankowego (TF, tissue factor) - białka, które co prawda jest fizjologicznym inicjatorem krzepnięcia krwi, ale które występując w krwiobiegu w nadmiarze, może przyczynić się do rozwoju powikłań zakrzepowych. Czynnik tkankowy uwalniany przez nowotwory może m.in. aktywować czynnik krzepnięcia $X$ oraz receptory aktywowane przez proteazy (protease-activated receptors - PAR), wynikiem czego jest zarówno wzrost generacji trombiny, jak i indukcja angiogenezy — procesy sprzyjające rozwojowi zakrzepicy. Wykazano, że u chorych na nowotwory istnieje dodatnia korelacja między zwiększoną zawartością TF w próbkach guzów nowotworowych pobranych w trakcie operacji a częstością występowania VTE. Ponadto w grupach pacjentów chorych na raka jajnika i raka trzustki zwiększona ekspresja TF wiązała się z gorszym rokowaniem [6].

Chemioterapia przeciwnowotworowa zwiększa ponad 6-krotnie ryzyko wystąpienia VTE [7]. Lekami niosącymi wzrost zagrożenia wystąpienia VTE są niektóre cytostatyki, inhibitory angiogenezy (bewacyzumab, talidomid, lenalidomid), leki hormonalne (tamoksifen, toramifen) i środki stymulujące erytropoezę (erytropoetyna, darbopoetyna). Cytostatyki zwiększają ryzyko zakrzepicy poprzez: 1) uszkodzenie endotelium, 2) zmniejszenie stężenia naturalnych inhibitorów krzepnięcia (białka C, białka S, antytrombiny) oraz 3) aktywację płytek krwi. Podobny jest mechanizm trombo-
Tabela I. Czynniki ryzyka rozwoju żylnej choroby zakrzepowo-zatorowej u pacjentów chorych na nowotwór złośliwy

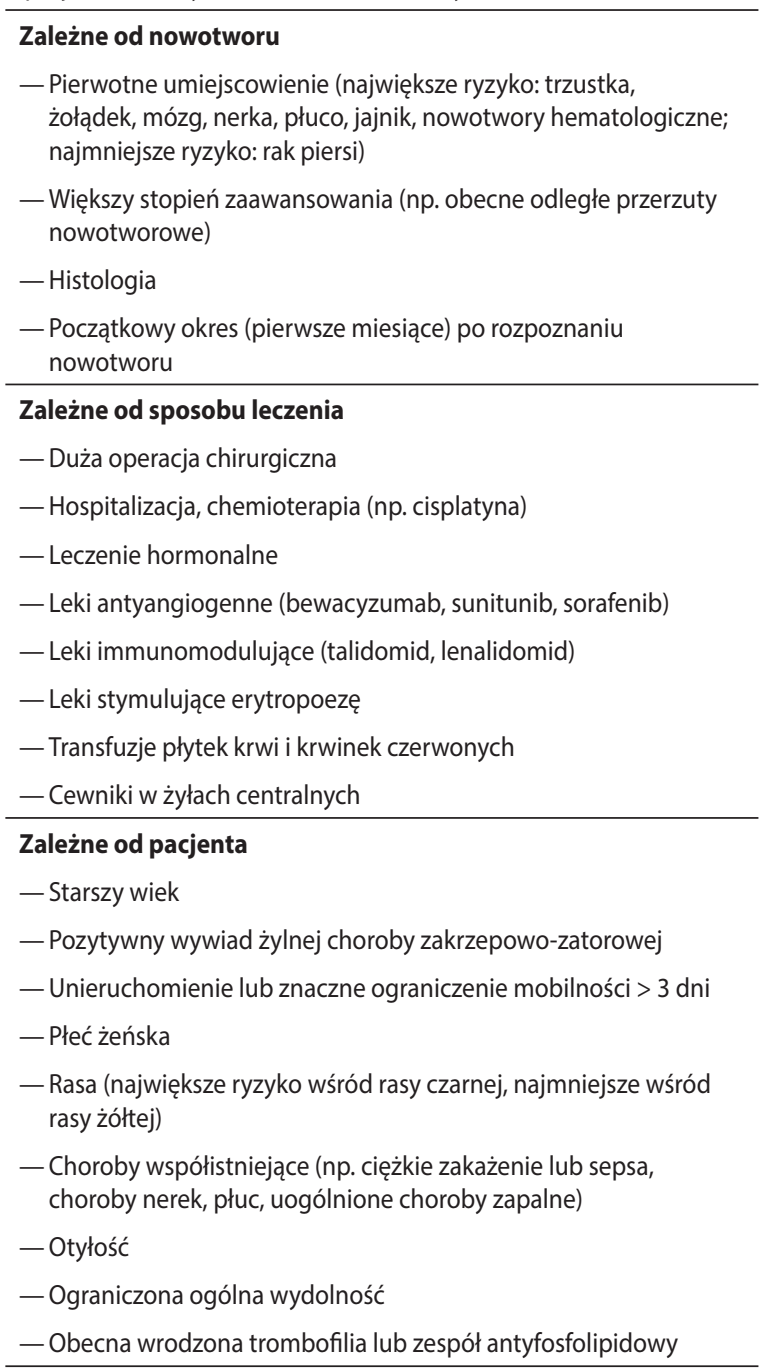

gennego działania inhibitorów angiogenezy. Działanie to ulega dodatkowemu wzmocnieniu po skojarzeniu inhibitorów angiogenezy z cytostatykami i/lub kortykosteroidami, na przykład u pacjentów ze szpiczakiem plazmocytowym (PCM — plasma cell myeloma) największe zagrożenie VTE niesie skojarzone stosowanie talidomidu i doksorubicyny, zaś u pacjentów z nawrotem PCM — lenalidomidu i dużych dawek deksametazonu [8]. Wśród pacjentów z rakiem nerki leczonych chemioterapią w skojarzeniu z talidomidem częstość VTE sięgnęła 43\% [9]. Metaanaliza obejmująca próby kliniczne, w których stosowano bewacyzumab w skojarzeniu z chemioterapią lub interferonem u chorych na różne rodzaje nowotworów złośliwych, wykazała, że bewacyzumab zwiększa względne ryzyko wystąpienia VTE o 33\% [10]. Inna analiza zbiorcza badań przeprowadzonych wśród pacjentek z rakiem piersi wykazała, że zastosowanie hormonalnej terapii adiuwantowej wiąże się z 1,5-7-krotnym wzrostem ryzyka wystąpienia VTE [11]. Operacje chirurgiczne, zwłaszcza rozległe zabiegi operacyjne, stanowią duży czynnik 
ryzyka rozwoju VTE u pacjentów chorych na nowotwory. Także wprowadzenie cewnika do żył centralnych znacznie zwiększa ryzyko wystąpienia miejscowej zakrzepicy u chorych na nowotwór, choć zakrzepica taka ma najczęściej przebieg bezobjawowy. Natomiast radioterapia per se raczej nie zwiększa zagrożenia zakrzepowego [12].

\section{Ocena ryzyka rozwoju żylnej choroby zakrzepowo-zatorowej u chorych na nowotwory leczonych w warunkach ambulatoryjnych oraz hospitalizowanych z powodu ostrej choroby niewymagającej interwencji chirurgicznej}

W ostatnich latach zwrócono uwagę na związek wybranych markerów laboratoryjnych ze skłonnością do VTE u pacjentów z nowotworem złośliwym. Khorana i wsp. [13] wykorzystali niektóre z tych markerów przy opracowaniu laboratoryjno-klinicznej skali oceny ryzyka wystąpienia VTE u 2701 pacjentów z nowotworem poddawanych chemioterapii w warunkach ambulatoryjnych (tab. II). Czas obserwacji wyniósł 6 miesięcy. Częstość VTE u pacjentów z grupy małego ryzyka (0 punktów) wyniosła 0,8\%, ryzyka średniego (1-2 punkty) $-1,8 \%$, a dużego ( $\geq 3$ punkty) $-7,1 \%$. Skala Khorany została wykorzystana przy stratyfikacji pacjentów do tromboprofilaktyki m.in. w badaniach PROTECHT oraz SAVE-ONCO [14, 15]. Wyniki obydwu badań potwierdziły zasadność włączania farmakologicznej profilaktyki przeciwzakrzepowej u pacjentów z dużym ryzykiem rozwoju VTE, czyli z $\geq 3$ punktami w omawianej skali. Grupa ekspertów austriackich rozszerzyła skalę Khorany o dwa dodatkowe parametry: stężenie D-dimeru i rozpuszczalnej P-selektyny, uzyskując bardzo wysoką czułość i swoistość swojej skali [16]. Głównym ograniczeniem „skali austriackiej” jest konieczność oznaczenia zawartości rozpuszczalnej P-selektyny, a więc wykonania testu, który nie jest powszechnie dostępny w laboratoriach hemostazy.

Ocenia się, że hospitalizacja zwiększa 8-krotnie ryzyko wystąpienia VTE oraz że $25 \%$ wszystkich przypadków VTE rozwija się u pacjentów hospitalizowanych [2]. W tabeli III przedstawiono czynniki ryzyka wystąpienia VTE u pacjentów hospitalizowanych niepoddawanych operacjom chirurgicznym, które składają się na tzw. padewską punktową skalę ryzyka wystąpienia VTE (Padua Prediction Score) [17]. Nowotwór złośliwy należy do grupy czterech największych czynników ryzyka rozwoju VTE w omawianej skali. Kakkar i wsp. [18] ocenili, że VTE jest odpowiedzialna za około $15 \%$ zgonów hospitalizowanych pacjentów chorych na nowotwory złośliwe, dlatego prawie każdy pacjent $z$ aktywnym nowotworem złośliwym hospitalizowany z powodu ostrej choroby niewymagającej interwencji chirurgicznej jest w grupie dużego ryzyka rozwoju VTE i powinien być objęty farmakologiczną profilaktyką przeciwzakrzepową. Jedynie duże zagrożenie ciężkimi krwawieniami usprawiedliwia odstąpienie od zastosowania antykoagulantów w tej grupie pacjentów. W tabeli IV przedstawiono punktową skalą oceny ryzyka wystąpienia krwawień u pacjentów hospitalizowanych z powodu ostrego schorzenia niewymagającego interwencji chirurgicznej, tzw. skalę IMPROVE [19]. Uzyskanie $\geq 7$ punktów w skali IMPROVE oznacza bardzo

Tabela II. Skala oceny ryzyka wystąpienia VTE u chorych na nowotwory poddawanych chemioterapii w warunkach ambulatoryjnych [na podstawie 12]

\begin{tabular}{|c|c|c|}
\hline Parametr oceniany & OR (95\% Cl) wystąpienia VTE & $\begin{array}{l}\text { Punktowe ryzyko } \\
\text { wystąpienia VTE }\end{array}$ \\
\hline \multicolumn{3}{|l|}{ Umiejscowienie nowotworu } \\
\hline Żołądek, trzustka & $4,3(1,2-15,6)$ & 2 \\
\hline $\begin{array}{l}\text { Płuco, chłoniak, narządy rodne, układ moczowo-płciowy } \\
\text { z wyłączeniem gruczołu krokowego }\end{array}$ & $1,5(0,9-2,7)$ & 1 \\
\hline Pierś, jelito grube i odbytnica, głowa i szyja & 1,0 (punkt odniesienia) & 1 \\
\hline \multicolumn{3}{|l|}{ Liczba płytek krwi przed chemioterapią } \\
\hline$>350 \times 10^{9} / 1$ & $1,8(1,1-3,2)$ & 1 \\
\hline $\begin{array}{l}\text { Stężenie hemoglobiny < } 10 \mathrm{~g} / \mathrm{dl} \text { bądź stosowanie leków } \\
\text { stymulujących erytropoezę }\end{array}$ & $2,4(1,3-4,2)$ & 1 \\
\hline \multicolumn{3}{|l|}{ Liczba leukocytów przed chemioterapią } \\
\hline$>11 \times 10^{9} / 1$ & $2,2(1,2-4)$ & 1 \\
\hline $\mathrm{BMI} \geq 35 \mathrm{~kg} / \mathrm{m}^{2}$ & $2,5(1,3-4,7)$ & 1 \\
\hline Liczba punktów & Kategoria ryzyka & Ryzyko wystąpienia VTE \\
\hline 0 & Małe & $0,8 \%$ \\
\hline 1,2 & Pośrednie & $1,80 \%$ \\
\hline$\geq 3$ & Duże & $7,1 \%$ \\
\hline
\end{tabular}

OR (odds ratio) — iloraz szans; 95\% Cl (confidence interval) — 95\% przedział ufności; VTE (venous thromboembolism) — żylna choroba zakrzepowo-zatorowa; BMI (body mass index) — wskaźnik masy ciała 
Tabela III. Czynniki ryzyka wystąpienia żylnej choroby zakrzepowo-zatorowej u pacjentów hospitalizowanych niepoddawanych operacjom chirurgicznym (tzw. padewska punktowa skala ryzyka wystąpienia VTE - Padua Prediction Score) [na podstawie 17])

\begin{tabular}{|c|c|}
\hline Parametr wyjściowy & $\begin{array}{l}\text { Liczba } \\
\text { punktów }\end{array}$ \\
\hline Aktywna choroba nowotworowa ${ }^{1}$ & 3 \\
\hline $\begin{array}{l}\text { Przebyty epizod VTE (z wykluczeniem zakrzepowego } \\
\text { zapalenia żył powierzchownych) }\end{array}$ & 3 \\
\hline Ograniczenie mobilności² & 3 \\
\hline Rozpoznana trombofilia ${ }^{3}$ & 3 \\
\hline $\begin{array}{l}\text { Uraz i/lub operacja chirurgiczna w ciągu miesiąca } \\
\text { poprzedzającego hospitalizację }\end{array}$ & 2 \\
\hline Podeszły wiek ( $\geq 70$ lat) & 1 \\
\hline Niewydolność serca i/lub układu oddechowego & 1 \\
\hline Ostry zawał serca lub udar niedokrwienny mózgu & 1 \\
\hline Ostra infekcja i/lub choroba reumatologiczna & 1 \\
\hline Otyłość (BMI $\geq 30)$ & 1 \\
\hline Aktualnie stosowane leczenie hormonalne & 1 \\
\hline Duże ryzyko wystąpienia VTE & $\geq 4$ \\
\hline
\end{tabular}

VTE (venous thromboembolism) —żylna choroba zakrzepowo-zatorowa; BMI (body mass index) - wskaźnik masy ciała

${ }^{1}$ Pacjenci z miejscowymi lub odległymi przerzutami nowotworowymi i/lub u których w ciągu ostatnich 6 miesięcy stosowano chemioterapię lub radioterapię

${ }^{2}$ Leżenie w łóżku ( $z$ możliwością korzystania z toalety) $\geq 3$ dni, wynikające z zalecenia lekarza lub ze stanu pacjenta

${ }^{3}$ Niedobór białka C i/lub białka S i/lub antytrombiny i/lub czynnik V Leiden i/lub mutacja G20210A genu protrombiny i/lub zespół antyfosfolipidowy

Tabela IV. Punktowa skala oceny ryzyka wystąpienia krwawień u pacjentów hospitalizowanych z powodu ostrego schorzenia niewymagającego interwencji chirurgicznej, tzw. skala IMPROVE [na podstawie 19]

\begin{tabular}{lc}
\hline Czynnik ryzyka krwawienia & $\begin{array}{c}\text { Liczba } \\
\text { punktów }\end{array}$ \\
\hline $\begin{array}{l}\text { Umiarkowane upośledzenie funkcji nerek GFR 30-59 vs } \\
\text { GFR } \geq 60 \text { ml/min/m² }\end{array}$ & 1 \\
Płeć męska & 1 \\
Wiek 40-84 lata vs < 40 lat & 1 \\
Nowotwór złośliwy & 2 \\
Choroba reumatyczna & 2 \\
Cewnik w żyle centralnej & 2 \\
Hospitalizacja na oddziale intensywnej opieki & 2,5 \\
medycznej lub kardiologicznej & \\
Ciężka niewydolność nerek GFR < 30 vs & 2,5 \\
GFR $\geq 60$ ml/min/m² & \\
Niewydolność wątroby (INR > 1,5) & 2,5 \\
Wiek $\geq 85$ lat vs < 40 lat & 3,5 \\
Liczba płytek < 50 × 109$/ I$ & 4 \\
Krwawienie w ciągu ostatnich 3 miesięcy & $>7$ \\
poprzedzających hospitalizację & 4 \\
Aktywne owrzodzenie w żołądku lub dwunastnicy & \\
\hline Duże ryzyko wystąpienia krwawień & 4 \\
\hline
\end{tabular}

GFR (glomerular filtration rate) — wskaźnik przesączania kłębuszkowego; INR (international normalized ratio) — międzynarodowy współczynnik znormalizowany duże zagrożenie poważnymi krwawieniami i może stanowić przeciwwskazanie do zastosowania antykoagulantów; jeśli jednak równocześnie ryzyko wystąpienia DVT jest duże, to można w takiej sytuacji sięgnąć po fizykalne metody przeciwdziałające DVT, np. pneumatyczny przerywany ucisk kończyn dolnych albo pończochy o stopniowanym ucisku, ewentualnie uciskowe bandażowanie.

Opublikowane ostatnio analizy wskazują, że stosowanie heparyn drobnocząsteczkowych (low molecular weight heparyn - LMWH), heparyny niefrakcjonowanej (unfractionated heparyn - UFH) bądź fondaparynuksu skutecznie chroni pacjentów hospitalizowanych z powodu ostrej choroby internistycznej przed rozwojem VTE, choć nie ma wpływu na redukcję śmiertelności [20-22]. Co prawda, skuteczność farmakologicznej tromboprofilaktyki nie była badana wybiórczo wśród pacjentów chorych na nowotwory złośliwe, ale chorzy na nowotwór stanowili istotną część populacji pacjentów niezabiegowych włączonych do wyżej wspomnianych analiz i dlatego wyniki tych analiz dotyczą w równym stopniu pacjentów z chorobą nowotworową.

Wciąż nierozstrzygnięte pozostaje zagadnienie czasu stosowania farmakologicznej tromboprofilaktyki u pacjentów hospitalizowanych z powodu ostrej choroby internistycznej. Choć wyniki niektórych badań wskazują na zasadność przedłużenia antykoagulacji na okres po hospitalizacji, to jednak ze względu na wzrost ryzyka wystąpienia powikłań krwotocznych u pacjentów długotrwale otrzymujących leki przeciwkrzepliwe większość ekspertów podziela obecnie opinię, że tromboprofilaktyka nie powinna trwać dłużej niż okres unieruchomienia i/lub hospitalizacji [23].

Poniżej przedstawiono zasady profilaktyki i leczenia VTE u pacjentów chorych na nowotwór złośliwy. Zasady te oparte są w głównej mierze, choć nie wyłącznie, na kompleksowych i cząstkowych wytycznych postępowania wVTE, sformułowanych przez 5 towarzystw naukowych (ACCP, ASCO, ESMO, NCCN i ISTH), opublikowanych w ciągu ostatnich 4 lat [23-31].

\section{Zasady profilaktyki żylnej choroby zakrzepowo-zatorowej u pacjentów chorych na nowotwór złośliwy leczonych w warunkach ambulatoryjnych}

1. U pacjentów chorych na nowotwór złośliwy otrzymujących chemioterapię w warunkach ambulatoryjnych należy systematycznie oceniać ryzyko wystąpienia VTE, np. stosując skalę Khorany (tab. II). W przypadku stwierdzenia dużego zagrożenia epizodem VTE należy rozważyć włączenie farmakologicznej tromboprofilaktyki, pod warunkiem że nie występują przeciwwskazania do stosowania antykoagulantów, z których najważniejsze to aktywne krwawienie oraz duże ryzyko wystąpienia istotnego klinicznie krwawienia. 
2. Zalecany antykoagulant $w$ omawianym wskazaniu to LMWH lub UFH lub fondaparynuks, przy czym u pacjentów z litymi guzami nowotworowymi najbardziej preferowane są LMWH. Dawkowanie musi być zgodne z charakterystyką produktu leczniczego.

3. Farmakologiczna tromboprofilaktyka jest szczególnie zalecana u pacjentów otrzymujących chemioterapię z powodu zaawansowanego raka trzustki. W tym przypadku zalecane są większe dawki LMWH niż w innych wskazaniach, np. dalteparyna 200 j.m./kg, co 24 h przez 4 tyg., a następnie $150 \mathrm{j} . \mathrm{m} . / \mathrm{kg}$, co $24 \mathrm{~h}$ lub enoksaparyna $1 \mathrm{mg} / \mathrm{kg}$, co $24 \mathrm{~h}[32,33]$.

4. Inną podgrupą pacjentów ze szczególnie istotnymi wskazaniami do profilaktyki VTE są pacjenci ze szpiczakiem plazmocytowym otrzymujący w ramach terapii przeciwnowotworowej talidomid lub lenalidomid (w połączeniu z kortykosteroidami i/lub cytostatykami). W tej podgrupie pacjentów obok LMWH można także stosować leki z grupy antagonistów witaminy K (vitamin K antagonists - VKA) oraz kwas acetylosalicylowy. W próbach klinicznych enoksaparyna była stosowana w dawce 40 mg co 24 h. Nie ma zgodności co do zalecanych wartości INR (international normalized ratio — międzynarodowy współczynnik znormalizowany) w trakcie stosowania VKA; część badaczy optuje za wartością INR około 1,5, inni za wartością pomiędzy 2,0 a 3,0. Część ekspertów (ISTH) nie zaleca stosowania VKA w tym wskazaniu. Sugerowana dawka kwasu acetylosalicylowego to 100 mg dziennie. LMWH jest preferowana w tej grupie pacjentów w przypadku pozytywnego osobistego wywiadu VTE [30, 34, 35].

5. U pacjentów chorych na nowotwór złośliwy otrzymujących chemioterapię w warunkach ambulatoryjnych, u których nie określono stopnia ryzyka wystąpienia VTE lub u których to zagrożenie oceniono jako małe, nie ma wskazań do farmakologicznej tromboprofilaktyki.

6. U pacjentów z omawianej grupy z dużym zagrożeniem wystąpienia zarówno powikłań zakrzepowo-zatorowych, jak i krwotocznych, należy rozważyć fizykalne metody tromboprofilaktyki, jak na przykład stopniowany ucisk kończyn dolnych.

7. Czas trwania tromboprofilaktyki w omawianej grupie pacjentów zwykle trwa około 3-4 miesięcy, licząc od włączenia nowego schematu chemioterapii. U pacjentów z szpiczakiem plazmocytowym tromboprofilaktyka jest stosowana przez cały okres podawania talidomidu/lenalidomidu.

8. Nowe antykoagulanty z grupy doustnych bezpośrednich inhibitorów lla i Xa nie są zalecane w omawianym wskazaniu.

9. U pacjentów z małopłytkowością, u których liczba płytek krwi wynosi $\geq 50 \times 10^{9} / \mathrm{l}$ i u których nie obserwuje się cech skazy krwotocznej, nie ma potrzeby redukowania dawek antykoagulantów. Jeśli liczba płytek krwi mieści się w przedziale 30-50 × 10\%/l i nie obserwuje się objawów skazy krwotocznej, decyzja o stosowaniu standardowych dawek antykoagulantów lub ich zmniejszeniu bądź zaniechaniu antykoagulacji powinna wynikać z indywidualnej analizy potencjalnych korzyści i strat związanych z określoną formą terapii. U pacjentów z liczbą płytek $<30 \times 10^{9} \mathrm{~L}^{-1}$ sugeruje się niestosowanie antykoagulacji [36].

\section{Zasady profilaktyki żylnej choroby zakrzepowo- -zatorowej u hospitalizowanych pacjentów chorych na nowotwór złośliwy niepoddawanych operacjom chirurgicznym}

1. U pacjentów onkologicznych hospitalizowanych z powodu ostrej choroby internistycznej należy rozważyć zastosowanie farmakologicznej tromboprofilaktyki, pod warunkiem braku przeciwwskazań do antykoagulacji, z których najważniejsze to aktywne krwawienie i duże ryzyko wystąpienia istotnego klinicznie krwawienia. Zalecanym antykoagulantem jest heparyna drobnocząsteczkowa, w drugim rzędzie heparyna niefrakcjonowana lub fondaparynuks. Tromboprofilaktykę należy stosować przez czas hospitalizacji (w próbach klinicznych było to najczęściej 6-14 dni).

2. Kwalifikując pacjentów z nowotworem złośliwym hospitalizowanych z powodu ostrej choroby internistycznej do tromboprofilaktyki, można posłużyć się padewską skalą oceny ryzyka wystąpienia VTE (tab. III) oraz skalą IMPROVE do oceny ryzyka wystąpienia krwawień (tab. IV).

3. Dawkowanie antykoagulantów powinno być zgodne z charakterystyką produktu leczniczego. W największych badaniach w omawianym wskazaniu stosowano dalteparynę 5000 j.m./d, enoksaparynę $40 \mathrm{mg} / \mathrm{d}$, tinzaparynę 4500 j.m./d bądź 75 j.m./kg/d, UFH 5000 j.m. co 8 h, fondaparynuks $2,5 \mathrm{mg} / \mathrm{d}$ [37-40].

4. Nowe antykoagulanty z grupy doustnych bezpośrednich inhibitorów lla i Xa nie są zalecane w omawianym wskazaniu.

5. Jak wykazano w próbach klinicznych, stosowanie farmakologicznej tromboprofilaktyki po wypisie ze szpitala prowadzi do zmniejszenia częstości występowania VTE, ale równocześnie wiąże się z istotnym zwiększeniem częstości występowania powikłań krwotocznych. Dlatego w omawianej grupie pacjentów nie zaleca się wydłużania czasu stosowania antykoagulantów po zakończonej hospitalizacji [41].

6. Hospitalizacja pacjentów onkologicznych jedynie w celu podania leków przeciwnowotworowych bądź wykonania procedur diagnostycznych nie stanowi wskazania do włączenia tromboprofilaktyki. 
7. U pacjentów chorych na nowotwór złośliwy hospitalizowanych z powodu ostrej choroby internistycznej, aktywnie krwawiących bądź obciążonych dużym ryzykiem wystąpienia powikłań krwotocznych, należy odstąpić od stosowania antykoagulantów i zastosować fizykalne metody prewencji DVT, np. przerywany pneumatyczny ucisk kończyn dolnych. Z chwilą ustąpienia krwawień należy jak najszybciej zastosować farmakologiczną tromboprofilaktykę, zgodnie z wyżej przedstawionymi zasadami.

8. Wyniki badań klinicznych przeprowadzonych w ostatnich latach wykazały, że zapadalność na objawową zakrzepicę związaną z obecnością cewników w żyłach centralnych jest stosunkowo mała i wynosi 3-4\% oraz że profilaktyka przeciwzakrzepowa nie jest w stanie wyeliminować lub wyraźnie zmniejszyć częstości tego powikłania. Dlatego nie zaleca się rutynowego stosowania pierwotnej profilaktyki przeciwzakrzepowej u pacjentów z cewnikiem w żyłach centralnych. Umiejscowienie cewnika wpływa na wielkość ryzyka wystąpienia zakrzepicy [26]. Najmniejsze ryzyko DVT towarzyszy cewnikowi założonemu do prawej żyły szyjnej, którego dystalny koniec znajduje się w okolicy połączenia żyły głównej górnej i prawego przedsionka.

9. U pacjentów chorych na nowotwory złośliwe i małopłytkowość hospitalizowanych z powodu ostrej choroby internistycznej należy rozważyć farmakologiczną profilaktykę VTE w standardowych dawkach, jeżeli liczba płytek krwi wynosi $\geq 50 \times 10^{9} \mathrm{~L}^{-1}$ i nie występują objawy skazy krwotocznej oraz nie stwierdza się dodatkowych zaburzeń hemostazy.

10. Jeśli liczba płytek krwi wynosi $25-50 \times 10^{9} \mathrm{~L}^{-1}$ i nie obserwuje się objawów skazy krwotocznej, decyzja o stosowaniu standardowych dawek antykoagulantów lub ich zmniejszeniu bądźzaniechaniu antykoagulacji powinna wynikać z indywidualnej analizy potencjalnych korzyści i strat związanych z określoną formą leczenia.

11. U pacjentów z liczbą płytek $<25 \times 10^{9} \mathrm{~L}^{-1}$ sugeruje się niestosowanie antykoagulacji; $w$ takiej sytuacji można zastosować mechaniczne formy tromboprofilaktyki (patrz pkt 12).
12. Jeśli małopłytkowości towarzyszy aktywna skaza krwotoczna i/lub współistnieją istotne zaburzenia innych elementów hemostazy, sugeruje się nie stosować farmakologicznej tromboprofilaktyki. W tej sytuacji zaleca się zastosowanie mechanicznych form profilaktyki VTE, np. pończoch o stopniowanym ucisku lub urządzenia do pneumatycznego ucisku.

13. U hospitalizowanych pacjentów onkologicznych, u których klirens kreatyniny $\geq 30 \mathrm{ml} / \mathrm{min}$, dawkowanie LMWH w ramach pierwotnej tromboprofilaktyki nie musi być modyfikowane (pod warunkiem braku innych przeciwwskazań do stosowania LMWH).

14. W przypadku zmniejszenia wartości klirensu kreatyniny $<30 \mathrm{ml} / \mathrm{min}$ podczas stosowania LMWH należy rozważyć monitorowanie aktywności anty-Xa w celu upewnienia się, czy nie dochodzi do kumulacji LMWH w organizmie, grożącej powikłaniami krwotocznymi. Innym sposobem postępowania jest zastąpienie LMWH heparyną niefrakcjonowaną, która nie kumuluje się w organizmie osoby z niewydolnością nerek.

\section{Zasady leczenia żyInej choroby zakrzepowo- -zatorowej u chorych na nowotwór złośliwy}

Celem leczenia VTE jest ograniczenie narastania zakrzepu (rzadziej jego rozpuszczenie lekami trombolitycznymi) oraz prewencja wystąpienia potencjalnie śmiertelnego $P E$, nawrotów VTE, zakrzepowo-zatorowego nadciśnienia płucnego, zespołu pozakrzepowego. Leczenie VTE u pacjentów onkologicznych jest trudniejsze niż u pacjentów bez nowotworu. Wyniki retrospektywnych i prospektywnych badań wykazały, że u pacjentów onkologicznych leczonych przeciwkrzepliwie po epizodzie VTE częstość nawrotów VTE jest większa 2-5 razy, zaś częstość dużych krwawień jest większa 2-6 razy w porównaniu z pacjentami mającymi chorobę zakrzepowo-zatorową i niechorującymi na nowotwór [3, 42, 43].

1. W leczeniu wstępnym VTE (definiowanym jako pierwsze 5-10 dni antykoagulacji) u chorych onkologicznych zaleca się stosowanie LMWH lub UFH lub fondaparynuksu w dawkach terapeutycznych zgodnie z zaleceniami producentów (preferowane są LMWH). W tabeli V przedsta-

Tabela V. Zalecane dawkowanie wybranych heparyn drobnocząsteczkowych w leczeniu wstępnym, podtrzymującym i przedłużonym żylnej choroby zakrzepowo-zatorowej u chorych na nowotwór złośliwy [na podstawie 42-47]

\begin{tabular}{ll}
\hline LMWH & Dawka i czas leczenia \\
\hline Enoksaparyna & Leczenie wstępne*: $1 \mathrm{mg} / \mathrm{kg}$ co $12 \mathrm{~h}$ przez 5-10 dni \\
& Leczenie podtrzymujące/przedłużone: $1,5 \mathrm{mg} / \mathrm{kg}$ co $24 \mathrm{~h}$ przez 3-6 miesięcy \\
Dalteparyna & Leczenie wstępne i podtrzymujące: $200 \mathrm{j} . \mathrm{m} . / \mathrm{kg}$ co $24 \mathrm{~h}$ przez 1 miesiąc \\
& Leczenie podtrzymujące i przedłużone: $150 \mathrm{IU} / \mathrm{kg}$ co $24 \mathrm{~h}$ przez 5 miesięcy \\
Tinzaparyna & Leczenie wstępne, podtrzymujące i przedłużone: $175 \mathrm{j} . / \mathrm{kg}$ co $24 \mathrm{~h}$ przez 3-6 miesięcy \\
\hline
\end{tabular}

LMWH (low-molecular-weigh heparin) - heparyna drobnocząsteczkowa

*W leczeniu wstępnym można zastosować także heparynę niefrakcjonowaną (pod kontrolą czasu, częściowej tromboplastyny po aktywacji — activated partial thromboplastin time - APTT) lub fondaparynuks w dawce: $5 \mathrm{mg}$ (u osób < 50 kg), 7,5 mg (u osób 50-100kg) bądź 10 mg (u osób > 100 kg) co 24 h 
wiono dawkowanie wybranych LMWH w leczeniu VTE u pacjentów chorych na nowotwór złośliwy.

2. Leczenie trombolityczne $z$ zastosowaniem rekombinowanego tkankowego aktywatora plazminogenu (rt-PA - recombinant tissue plazminogen activator) lub streptokinazy jest uzasadnione wyłącznie w przypadku najciężej przebiegających epizodów VTE, np. PE wysokiego ryzyka (rzadziej pośredniego ryzyka) albo masywnej zakrzepicy żył głębokich w odcinku biodrowo-udowym z upośledzeniem odpływu krwi z kończyny dolnej. Stosowanie systemowej trombolizy jest obciążone 12-procentowym ryzykiem wystąpienia ciężkich powikłań krwotocznych.

3. Po zakończeniu leczenia wstępnego rozpoczyna się okres leczenia podtrzymującego (maintenance), który trwa do 3 miesięcy od epizodu VTE. Stosowanie antykoagulantów po upływie 3 miesięcy od wystąpienia VTE określa się mianem leczenia przedłużonego (extended). W przeciwieństwie do innych populacji u chorych na nowotwór złośliwy w leczeniu podtrzymującym i przedłużonym VTE zaleca się stosowanie LMWH, które wykazują przewagę nad VKA, wyrażającą się zarówno mniejszym odsetkiem nawrotów VTE, jak i mniejszym odsetkiem powikłań krwotocznych (dawkowanie w tabeli V) [43-48].

4. LMWH należy stosować co najmniej przez 3-6 miesięcy od chwili rozpoznania epizodu VTE. Po tym okresie decyzja o stosowaniu antykoagulantów (LMWH lub VKA) jest uzależniona od aktywności procesu nowotworowego, analizy potencjalnych korzyści i strat związanych ze stosowaniem antykoagulacji oraz preferencji chorego.

5. Heparyny drobnocząsteczkowe są eliminowane z ustroju z moczem. U pacjentów z niewydolnością nerek przewlekłe stosowanie LMWH może prowadzić do kumulacji leku w organizmie, co zagraża wystąpieniem krwawień. U pacjentów z klirensem kreatyniny $<30 \mathrm{ml} / \mathrm{min}$ otrzymujących przewlekle LMWH należy oznaczać aktywność anty-Xa. Przy podawaniu LMWH we wstrzyknięciach podskórnych co $12 \mathrm{~h}$ sugerowany przedział terapeutyczny dla aktywności anty-Xa wynosi 0,6-1,2 j.m./ml. Alternatywą dla LMWH są UFH i VKA, które można bezpiecznie stosować u pacjentów z niewydolnością nerek (leki te nie są wydalane z moczem).

6. W przypadku ostrego epizodu VTE u pacjenta onkologicznego z liczbą płytek krwi $<50 \times 10^{9} \mathrm{~L}^{-1}$, ale bez objawów skazy krwotocznej:

a) sugeruje się stosowanie terapeutycznych dawek antykoagulantów wraz z toczeniem koncentratów krwinek płytkowych w celu utrzymywania liczby płytek krwi $\geq 50 \times 10^{9} \mathrm{~L}^{-1}$. Jeśli utrzymanie liczby płytek krwi $\geq 50 \times 10^{9} \mathrm{~L}^{-1}$ jest niemożliwe, decyzja o stosowaniu terapeutycznych dawek antykoagulantów lub redukcji tych dawek powinna opierać się na indywidualnej ocenie potencjalnych korzyści i strat związanych z poszczególnymi opcjami terapeutycznymi;

b) jeśli dzięki przetaczaniu koncentratu krwinek płytkowych udaje się utrzymać liczbę płytek krwi w zakresie 20-50 $\times 10^{9} \mathrm{~L}^{-1}$, sugeruje się redukcję dawek antykoagulantów do 50\% dawki leczniczej (w uzasadnionych przypadkach utrzymuje się dawki lecznicze);

c) jeśli liczba płytek krwi pomimo przetaczania koncentratów krwinek płytkowych wynosi $<20 \times 10^{9} \mathrm{~L}^{-1}$, sugeruje się odstawienie antykoagulantów.

7. Jeśli pojawią się niewielkie objawy skazy krwotocznej niewykazujące tendencji do nasilania w trakcie antykoagulacji, powyższe zasady nie muszą być modyfikowane.

8. W przypadku ostrego epizodu VTE u pacjenta chorego na nowotwór złośliwy i z małopłytkowością oraz istotnymi objawami skazy krwotocznej sugeruje się niestosowanie antykoagulantów, choć ostateczna decyzja musi opierać się na indywidualnej ocenie potencjalnych korzyści i strat związanych z antykoagulacją lub zaniechaniem jej stosowania.

9. Jeśli przetaczanie koncentratu krwinek płytkowych jest niemożliwe bądź przeciwwskazane oraz w sytuacji kiedy małopłytkowość objawia się istotną skazą krwotoczną, a ostry epizod DVT kończyn dolnych może zagrażać życiu pacjenta, należy rozważyć implantację czasowego filtra do żyły głównej dolnej w celu prewencji PE. Z chwilą ustąpienia przeciwwskazań do antykoagulacji należy natychmiast usunąć filtr i włączyć odpowiednie dawki leków przeciwkrzepliwych. Dane piśmiennictwa wskazują, że wszczepienie filtra do żyły głównej dolnej może wpływać na pogorszenie odległego rokowania (m.in. częstsze nawroty zakrzepicy żył głębokich) w porównaniu z pacjentami chorymi na VTE, u których filtra nie wszczepiono (dane te dotyczą także pacjentów chorych onkologicznie).

10. W przewlekłym leczeniu VTE u pacjenta chorego na nowotwór złośliwy i małopłytkowość sugeruje się:

a) zmniejszenie dawki heparyny drobnocząsteczkowej o 50\%, jeśli liczba płytek zawiera się w przedziale 25-50 $\times 10^{9} \mathrm{~L}^{-1}$ i nie występują krwawienia;

b) odstawienie antykoagulacji, jeśli liczba płytek wynosi $<25 \times 10^{9} \mathrm{~L}^{-1} \mathrm{i} /$ lub występuje istotna skaza krwotoczna.

11. W przypadku nawrotów VTE u chorych na nowotwory $w$ trakcie antykoagulacji istnieją 3 sposoby postępowania: 1) zamiana VKA na LMWH (w dawkach terapeutycznych), jeśli do nawrotu VTE doszło $w$ trakcie stosowania VKA; 2) zwiększenie dawki LMWH u pacjentów stale otrzymujących LMWH, najlepiej pod kontrolą aktywności anty-Xa (sugerowany zakres terapeutyczny dla LMWH stosowanej co $24 \mathrm{~h}$ wynosi 1,6-2,0 j./ml, zaś dla LMWH stosowanej co $12 \mathrm{~h}-0,6-1,2 \mathrm{j}$./ml [oznaczenie 
anty-Xa wykonuje się $4 \mathrm{~h}$ po ostatnim wstrzyknięciu LMWH]); 3) wszczepienie filtra do żyły głównej u pacjentów z DVT kończyn dolnych i nawrotem PE pomimo antykoagulacji.

12. W leczeniu zakrzepicy związanej z cewnikiem w żyle centralnej u pacjenta chorego na nowotwór preferuje się LMWH, ale VKA można także stosować. Minimalny czas antykoagulacji to 3 miesiące. Dawkowanie antykoagulantów jest takie samo jak w innych przypadkach VTE. Wystąpienie zakrzepicy związanej z cewnikiem w żyle centralnej nie stanowi wskazania do usunięcia cewnika, jeśli cewnik jest drożny i nie rozwinęło się zakażenie.

13. Do chwili obecnej nie zebrano dostatecznie silnych dowodów naukowych, aby zalecać stosowanie antykoagulantów z grupy doustnych bezpośrednich inhibitorów lla i Xa u pacjentów z ostrym epizodem VTE w przebiegu choroby nowotworowej [49].

\section{Podsumowanie}

Biorąc pod uwagę, że VTE jest drugą po samym nowotworze najczęstszą przyczyną zgonu chorych onkologicznych, każdy specjalista onkolog powinien posiąść wiedzę o zasadach leczenia i prewencji DVT i PE. Najważniejsza jest systematyczna ocena ryzyka wystąpienia VTE zarówno u pacjentów leczonych ambulatoryjnie, jak i u chorych hospitalizowanych. Zakwalifikowanie pacjenta do grupy dużego ryzyka rozwoju VTE powinno wiązać się z natychmiastowym włączeniem farmakologicznej profilaktyki przeciwzakrzepowej, pod warunkiem braku przeciwwskazań do jej zastosowania. U pacjenta zagrożonego poważnymi powikłaniami krwotocznymi można sięgnąć po fizykalne metody prewencji DVT. Antykoagulantem pierwszego wyboru w prewencji i leczeniu VTE u chorych onkologicznych pozostają heparyny drobnocząsteczkowe.

\section{Prof. dr hab. med. Jerzy Windyga}

Klinika Zaburzeń Hemostazy i Chorób Wewnętrznych

oraz Zakład Hemostazy i Chorób Metabolicznych

Instytut Hematologii i Transfuzjologii

ul. I. Gandhi 14, 02-776 Warszawa

e-mail:jwindyga@ihit.waw.pl

\section{Otrzymano i przyjęto do druku: 23 lipca 2015 r.}

Na podstawie wykładu wygłoszonego podczas Warszawskiej Konferencji Onkologicznej 28 listopada 2014 r.

\section{Piśmiennictwo}

1. Khorana AA, Francis CW, Culakova E i wsp. Thromboembolism is a leading cause of death in cancer patients receiving outpatient chemotherapy. J Thromb Haemost 2007; 5: 632-634.

2. Tagalakis V, Wharin C, Kahn SR. Comprehensive update on the prevention and treatment of venous thromboebolism in cancer patients. Semin Thromb Hemost 2013; 39: 127-140.

3. Prandoni P, Lensing AW, Piccioli A i wsp. Recurrent venous thromboembolism and bleeding complications during anticoagulant treatment in patients with cancer and venous thrombosis. Blood 2002; 100: 3484-3488.
4. Khorana AA, Francis CW, Culakova E i wsp. Frequency, risk factors, and trends for venous thromboembolism among hospitalized cancer patients. Cancer 2007; 110: 2339-2346.

5. Bloom JW, Doggen CJ, Osanto S i wsp. Malignancies, prothrombotic mutations, and the risk of venous thrombosis. JAMA 2005; 293: 715-722.

6. Khorana AA. Cancer and thrombosis: implications of published guidelines for clinical practice. Ann Oncol 2009; 20: 1619-1630.

7. Heit JA, Silverstein MD, Mohr DN i wsp. Risk factors for deep vein thrombosis and pulmonary embolism: a population-based case-control study. Arch Intern Med 2000; 160: 809-815.

8. Bennett $\mathrm{CL}$, Angelotta $\mathrm{C}$, Yarnold PR i wsp. Thalidomide- and lenalidomide-associated thromboembolism among patients with cancer. JAMA 2006; 296: 2558-2560.

9. Desai AA, Vogelzang NJ, Rini BI i wsp. A high rate of venous thromboembolism in a multi-institutional phase II trial of weekly intravenous gemcitabine with continuous infusion fluorouracil and daily thalidomide in patients with metastatic renal cell carcinoma. Cancer 2002; 95: 1629-1636.

10. Nalluri SR, Chu D, Keresztes R i wsp. Risk of venous thromboembolism with the angiogenesis inhibitor bevacizumab in cancer patients: a meta-analysis. JAMA 2008; 300: 2277-2285.

11. McCaskill-Stevens W, Wilson J, Bryant J i wsp. Contralateral breast cancer and thromboembolic events in African American women treated with tamoxifen. J Nat/ Cancer Inst 2004; 96: 1762-1769.

12. Khorana AA. Cancer-associated thrombosis: updates and controversies. Hematology Am Soc Hematol Educ Program 2012; 2012:626-630.

13. Khorana AA, Kuderer NM, Culakova E i wsp. Development and validation of a predictive model for chemotherapy-associated thrombosis. Blood 2008; 111: 4902-4907.

14. Agnelli G, Gussoni G, Bianchini Ci iwsp. Nadroparin for the prevention of thromboembolic events in ambulatory patients with metastatic or locally advanced solid cancer receiving chemotherapy: a randomised, placebo-controleed, double-blind study. Lancet Oncol 2009; 10: 943-949.

15. Agnelli G, George DJ, Kakkar AK i wsp. Semuloparin for thromboprophylaxis in patients receiving chemotherapy for cancer. N Engl J Med 2012; 366: 601-609.

16. Pabinger I, Thaler J, Ay C. Biomarkers for prediction of venous thromboembolism in cancer. Blood 2013; 122: 2011-2018.

17. Barbar S, Noventa F, Rossetto V i wsp. A risk assessment model for the identification of hospitalized medical patients at risk for venous thromboembolism: the Padua Prediction Score. J Thromb Haemost 2010; 8: 2450-2457.

18. Kakkar AK, Levine M, Pinedo HM i wsp. Venous thrombosis in cancer patients: insights from a frontline survey. The Oncologist 2003; 8: 381-388.

19. Decousus H., Tapson V.F., Bergmann JF. i wsp. Factors at admission associated with bleeding risk in medical patients. Chest 2011; 139:69-79.

20. Denatli F, Douketis JD, Gianni M i wsp. Metaanalysis: anticoagulant prophylaxis to prevent symptomatic venous thromboembolism in hospitalized medical patients. Ann Intern Med 2007; 146: 278-288.

21. Lloyd NS, Douketis JD, Moinuddin I i wsp. Anticoagulant prophylaxis to prevent asymptomatic deep vein thrombosis in hospitalized medical patients: a systemic review and meta-analysis. J Thromb Haemost 2008; 6: 405-414.

22. Alikhan R, Cohen AT.WITHDRAWN: heparin for the prevention of venous thromboembolism in general medical patients (excluding stroke and myocardial infarction). Cochrane Database Syst Rev 2010; (2): CD003747.

23. Kahn SR, Lim W, Dunn AS i wsp. Prevention of VTE in nonsurgical patients. Antithrombotic therapy and prevention of thrombosis, 9th ed: American College of Chest Physicians Evidence-Based Clinical Practice Guidelines. Chest 2012; 141 (2 Suppl): e195S-e226S.

24. Farge D, Debourdeau P, Beckers M i wsp. International clinical practice guidelines for the treatment and prophylaxis of venous thromboembolism in patients with cancer. J Thromb Haemost 2013; 11: 56-70.

25. Mandala M, Falanga A, Roila F I wsp. Management of venous thromboembolism (VTE) in cancer patients: ESMO clinical practice guidelines. Ann Oncol 2011; 22 Suppl. 6: vi85-vi92.

26. Debourdeau P, Farge D, Beckers M i wsp. International clinical practice guidelines for the treatment and prophylaxis of thrombosis associated with central venous catheters in patients with cancer. J Thromb Haemost 2013; 11: 71-80.

27. National Comprehensive Cancer Network. Clinical Practice Guidelines in Oncology Venous Thromboembolic Disease version 2.2013. Available at: http://www.nccn.org/professionals/physician_gls/pdf/vte.

28. Lyman GH, Khorana AA, Kuderer NM i wsp. Venous thromboembolism prophylaxis and treatment in patients with cancer: American Society of Clinical Oncology clinical practice guideline update. J Clin Oncol 2013; 31:2189-2204. 
29. Di Nisio M, Carrier M, Lyman GH i wsp. Prevention of venous thromboembolism in hospitalized medical cancer patients: guidance from the SSC of the ISTH. J Thromb Haemost 2014; 12: 1746-1749.

30. Khorana AA, Otten HM, Zwicker J i wsp. Prevention of venous thrombembolism in cancer outpatients: guidance from the SSC of the ISTH. J Thromb Haemost 2014; 12: 1928-1931.

31. Carrier M, Khorana AA, Zwicker J i wsp. Management of challenging cases of patients with cancer-associated thrombosis including recurrent thrombosis and bleeding: guidance from the SSC of the ISTH. JThromb Haemost 2013; 11: 1760-1765.

32. Reiss H, Pelzer U, Hilbig A i wsp. Rationale and design of PROSPECT-CONKO 004: a prospective, randomized trial of simultaneous pancreatic cancer treatment with enoxaparin and chemotherapy. BMC Cancer 2008; 8: 361.

33. Reiss $\mathrm{H}$, Pelzer $\mathrm{U}$, Optiz B i wsp. A prospective, randomized trial of simultaneous pancreatic cancer treatment with enoxaparin and chemotherapy. Final results of the CONKO-004 trial. J Clin Oncol 2010 ASCO Annual Meeting Abstracts 2010; 28 (suppl. 15): 4033.

34. Palumbo A, Cavo M, Bringhen S i wsp. Aspirin, warfarin, or enoxaparin thromboprophylaxis in patients with multiple myeloma treated with thalidomide: a phase III, open-label, randomized trial. J Clin Oncol 2011; 29: 986-993.

35. Larocca A, Cavallo F, Bringhen S i wsp. Aspirin or enoxaparin thromboprophylaxis in patients with newly diagnosed multiple myeloma treated with lenalidomide. Blood 2012; 119: 933-939.

36. Connors JM. Prophylaxis against venous thromboembolism in ambulatory patients with cancer. N Engl J Med 2014; 370: 2515-2519.

37. Cohen AT, Davidson BL, Gallus AS i wsp. Efficacy and safety of fondaparinux for the prevention of venous thromboembolism in older acute medical patients: randomised placebo controlled trial. BMJ 2006; 332: 325-329.

38. Alikhan R, Cohen AT, Combe S i wsp. Prevention of venous thromboembolism in medical patients with enoxaparin: a subgroup analysis of the MEDENOX study. Blood Coagul Fibrinolysis 2003; 14: 341-346.

39. Leizorovicz A, Cohen AT, Turpie AG i wsp. Randomized, placebo-controlled trial of dalteparin for the prevention of venous thromboembolism in acutely ill medical patients. Circulation 2004; 110: 874-879.
40. Samama MM, Cohen AT, Darmon JY i wsp. A comparison of exoxaparin with placebo for the prevention of venous thromboembolism in acutely ill medical patients. Prophylaxis in medical patients with Enoxaparin Study Group. N Engl J Med 1999; 341: 793-800.

41. Hull RD, Schellong SM, Tapson VF i wsp. Extended-duartion venous thromboembolism prophylaxis in acutely ill medical patients with recently reduced mobility: a randomized trial. Arch Intern Med 2010; 153: 8-18.

42. Hutten BA, Prins MH, Gent M i wsp. Incidence of recurrent thromboembolic and bleeding complications among pastients with venous thromboembolism in relation to both malignancy and achieved international normalized ratio: a retrospective analysis. $J$ Clin Oncol 2000; 18: 3078-3083.

43. Hull R D, Pineo G F, Brant R F i wsp. Long-term low-molecular-weight heparin versus usual care in proximal-vein thrombosis patients with cancer. Am J Med 2006; 119: 1062-1072.

44. Lee A Y, Levine M N, Baker R I i wsp. Low-molecular-weight heparin versus coumarin for the prevention of recurrent venous thromboembolism in patients with cancer. N Engl J Med 2003; 349: 146-153.

45. Meyer G, Marjanovic Z, Valcke J i wsp. Comparison of low-molecular weight heparin and warfarin for the secondary prevention of venous thromboembolism in patients with cancer: a randomized controlled study. Arch Intern Med 2002; 162: 1729-1735.

46. Deitcher SR, Kessler CM, Merli G i wsp. Secondary prevention of venous thromboembolic events in patients with active cancer: enoxaparin alone versus initial enoxaparin followed by warfarin for a 180-day period. Clinical Appl Thromb/Hemost 2006; 12: 389-396.

47. Lee AY, Peterson EA. Treatment of cancer-associated thrombosis. Blood 2013; 122: 2310-2317.

48. Barsam SJ, Patel R, Arya R. Anticoagulation for prevention and treatment of cancer-related venous thromboembolism. Br J Haematol 2013; 161: 764-777.

49. van der Hulle T, den Exter PL, Kooiman J i wsp. Meta-analysis of the efficacy and safety of new oral anticoagulants in patients with cancer-associated acute venous thromboembolism. J Thromb Haemost 2014; 12: 1116-1120. 